\title{
WhatsApp and political instability in Brazil: targeted messages and political radicalisation
}

\author{
Rafael Evangelista \\ Laboratory of Advanced Studies on Journalism (Labjor), State University of Campinas (Unicamp), \\ Brazil, rae@unicamp.br
}

Fernanda Bruno

Communication and culture, Federal University of Rio de Janeiro (UFRJ), Brazil

Published on 31 Dec 2019 | DOI: 10.14763/2019.4.1434

\begin{abstract}
In the 2018 presidential election, Brazil elected a fringe congressman, Jair Bolsonaro, despite his radical rhetoric that would suffice to shake the public image of any candidate in the world and the lack of traditional resources of his campaign. One of the hypotheses for this electoral success is that his campaign built a specific communication strategy that used internet platforms to communicate directly with different groups of voters. We describe the Brazilian electoral scenario of 2018, focusing on the use of the messaging app WhatsApp. We discuss how Bolsonaro's campaign tapped into sentiments and perceptions spread by the legacy media, adding a stronger conservatism. We gather evidence of centralised management of WhatsApp chat groups by political actors that emerge from the work of computer scientists research, newspaper articles and our own ethnographic work. The radicalisation of Brazilian politics could be partially explained as an effect of the use of political micro-targeting in a highly concentrated news media ecosystem, and zero-rating policies that fuels WhatsApp popularity, a platform with affordances that favours the spread of misinformation.
\end{abstract}

Keywords: Political micro-targeting, Surveillance, Social media, Visibility, Brazil

\section{Article information}

Received: 16 Jul 2019 Reviewed: 21 Nov 2019 Published: 31 Dec 2019

Licence: Creative Commons Attribution 3.0 Germany

Competing interests: The author has declared that no competing interests exist that have influenced the text.

URL:

http://policyreview.info/articles/analysis/whatsapp-and-political-instability-brazil-targeted-messagesand-political

Citation: Evangelista, R. \& Bruno, F. (2019). WhatsApp and political instability in Brazil: targeted messages and political radicalisation. Internet Policy Review, 8(4). DOI: 10.14763/2019.4.1434

This paper is part of Data-driven elections, a special issue of Internet Policy Review guestedited by Colin J. Bennett and David Lyon. 


\section{INTRODUCTION}

After 21 years of military dictatorship, followed by a short period of political instability, the political scene in Brazil was dominated by two major parties that, between them, held the presidency until 2018. Both were moderate with a large membership base, had many representatives in Congress and received constant coverage in the legacy media as representatives of a more westernized democratic process. However, in the 2018 elections, the country elected as president a niche congressman, Jair Bolsonaro, a member of a small party (PSL) with almost no registered supporters, who had been relatively unknown until some four years earlier, when he started to make appearances on popular and comic TV shows, on which he combined extremist rhetoric with praise for the military dictatorship. Bolsonaro's election surprised local and international politicians and intellectuals, in part because his campaign lacked a traditional political structure, but mainly because of his radical rhetoric, which frequently included misogynistic and racist statements that would be sufficient to shake the public image of any candidate anywhere in the world (Lafuente, 2018), but which were even more shocking in a country marked by social inequalities and racial diversity.

One of the hypotheses for Bolsonaro's electoral success is that his campaign and some supporters developed a specific communication strategy based on the intense use of social media, in which the use of WhatsApp chat groups, micro-targeting and disinformation to reach different groups of voters had significant relevance. Albeit not always in a coordinated way, several platforms were used: YouTube, with videos of alt-right political analyses, lectures about "politically incorrect" history and amateur journalism; Facebook, with its pages and groups for distributing content and memes; and Twitter/Instagram, especially as sites for posting political and media content (the last three platforms mentioned were also widely used by the candidate himself to post messages and live videos on his official profile). Davis and Straubhaar (2019) point out that "legacy media, popular right-wing Facebook groups, and networks formed around the communication network WhatsApp fueled "antipetismo" ${ }_{1}$, stressing that WhatsApp was particularly instrumental to cement Bolsonaro's victory. Addressing the emergence of what she calls "digital populism", Cesarino (2019) discusses the formation of a polarised digital bubble largely anchored on WhatsApp chat groups.

We focus our analysis on WhatsApp, examining the use of encrypted groups containing up to 256 members reflecting specific interests (religious, professional, regional, etc.). Smartphones and WhatsApp "were not as extensively available in Brazil during the previous [2014] presidential election" (Cesarino, 2019), and we aim to show that WhatsApp has technical specificities and was susceptible to an electoral strategy that justifies particular attention. Several media reports stress the role played by WhatsApp in the 2018 elections. Analysing the Brazilian elections, our goal is also to contribute to the decoupling of "research from the US context" and help with the understating of "macro, meso and micro level factors that affect the adoption and success of political micro-targeting (PMT) across different countries" (Bodó, Helberger, \& Vreese, 2017). The Global South in general has been associated with an increase in "computational propaganda" in recent years (Woolley \& Howard, 2017; Bradshaw \& Howard, 2018).

Because of its closed, encrypted architecture, which restricts visibility for researchers and public authorities, the relative anonymity afforded by the use of only telephone numbers as identifiers by groups administrators, and the limited number of members in a group, which favours audience segmentation, WhatsApp is the platform that poses the greatest challenges for those 
investigating information dynamics during elections. It has also been shown that, because of these characteristics, WhatsApp played a crucial role in the spread of misinformation during the Brazilian 2018 elections (Tardáguila, Benevenuto, \& Ortellado, 2018; Davis \& Straubhaar, 2019; Junge, 2019) and in the development of a disinformation strategy that not only was on the edge of the law (Melo, 2019; Avelar, 2019; Magenta, Gragnani \& Souza, 2018) but also exploited features of the platform's architecture that help to render coordinated strategies invisible and favour group segmentation.

Although widely used in Brazil as a means of communication, only recently has WhatsApp use been tackled as a research subject in elections. Moura and Michelson (2017) evaluated its use as a tool for mobilising voters, and Resende et al. (2019) conducted groundbreaking research on the dynamics of political groups on WhatsApp. However, little has been said on the interrelation between a historical context and its interplay with new platforms, media technologies and novel campaign strategies that rely on surveillance. In this sense, surveillance shows up as a new mode of power (Haggerty \& Ericson, 2006) with direct impact on the election process, with implications for democracy (Bennett, 2015). This article challenges the idea that political microtargeting (PMT) is elections as usual (Kreiss, 2017), showcasing its connection with disinformation practices and a process of political radicalisation in a specific empirical context, and stresses that PMT functions as part of an (mis)information ecosystem.

In this article, we discuss the Brazilian institutional, political and media context that paved the way for Jair Bolsonaro to become president in what was an atypical election result that surprised the vast majority of political analysts. We describe and discuss the use of a particular social media platform, WhatsApp, which instead of functioning as an instant messaging application was weaponised as social media during the elections. Based on an analysis of a sample of the most widely distributed images on this platform during the month immediately prior to the first round of the elections, in which Bolsonaro won $46.03 \%$ of the valid votes, we argue that messages were partially distributed using a centralised structure, built to manage and to stimulate members of discussion groups, which were treated as segmented audiences. Our ambition is to correctly address a specific and concrete use of data in an electoral campaign and to avoid any type of hype around PMT or data-driven strategies (Bodó et al., 2017; BaldwinPhilippi, 2017). In this case, platforms and data are not used as much to scientifically inform broad campaign strategies (Issenberg, 2012), but are more connected to disinformation/misinformation processes.

\section{THE BRAZILIAN CONTEXT AND THE RISE OF BOLSONARO AS A POLITICAL AND MEDIA "MYTH"}

Brazil is a federal republic with relatively independent states but considerable power centralised in the federal executive and legislatures. The regime is presidential, and an election is held every four years for president (who may run once for re-election), state governors, state congressmen and federal deputies and senators; federal deputies and senators represent their states in two legislative houses, the Chamber of Deputies and the Federal Senate. The president of the Chamber of Deputies is the second in line to the presidency (after the vice president, who is elected on the same slate as the president), and it is the responsibility of the legislature to investigate and, if necessary, try the president of the republic for "crimes of responsibility", which can lead to impeachment and removal from office. 
Voting is compulsory and electors do not need to be members of a party to vote. Failure to vote is punished with a small fine (approximately \$2.00 USD). Abstentions are typically in the region of $20 \%$; in the last elections the figure reached $20.3 \%$, the highest in the last 20 years.

Federal and state elections are held every four years, and municipal elections occur in between. Candidates must be members of legally constituted political parties to stand for election. Elections for executive office are held in two rounds, and the two candidates with the most votes in the first round compete in a run-off unless one of them has $50 \%+1$ of the valid votes in the first round.

The political system is extremely fragmented (Nascimento, 2018), and there is frequent switching between parties, particularly between smaller associations. In general, congressional representatives who belong to these smaller associations are known as the "lower clergy" and form a bloc characterised by clientelism (Hunter \& Power, 2005) and cronyism. Armijo \& Rhodes (2017) argue that "cronyism may tip into outright corruption, or direct payments by private actors for preferential treatment by state officials", pointing out that Brazilian elections are very expensive and were, at least until recently, heavily funded by the private sector. Parties form coalitions to take part in the elections, and the seats in the Chamber of Deputies are distributed according to the number of votes the coalitions or parties receive and are then allocated within the coalitions according to the number of votes each candidate receives. In his almost 30 consecutive years as a federal deputy, Jair Bolsonaro was known as a member of the "lower clergy" and was affiliated with no less than nine different political parties. A former member of the armed forces, when elected congressman, his votes came mainly from efforts that benefited that sector (Foley, 2019), and also from his criticism of human rights and his position in favour of harsher criminal laws and more vigorous police action.

Brazilian elections historically were financed with a combination of public funds and limited private donations from individuals and companies 2. Public funds are shared between the parties mainly according to the number of seats they have in Congress. Parties are also entitled to television and radio airtime, for which broadcasting companies receive tax exemptions. Political advertisements paid for by parties are prohibited.

Radio and TV airtime was traditionally considered one of the most important factors in a presidential election. However, in the last election, the candidate with the most time in these media ended up in fourth position (Geraldo Alckmin, PSDB, with 44.3\% of the airtime), while Bolsonaro, who had little more than $1 \%$ of the total airtime, won the first round. Fernando Haddad (PT), who came second, had 19.1\% of the airtime (Ramalho, 2018; Machado, 2018).

The Brazilian broadcasting system is concentrated in the hands of a few family groups and, more recently, an evangelical minister from a non-denominational church (Davis \& Straubhaar, 2019). These groups own TV and radio networks, newspapers and websites around the country. The editorial line is economically conservative, although some of the companies (e.g., Rede Globo) have a more liberal attitude in terms of customs (Joyce, 2013).

An appreciation of the Brazilian political scene is also important to understand Bolsonaro's rise. From the middle of the second term in office of Luis Inácio Lula da Silva, when the first accusations of corruption involving members of the government appeared, much of the domestic press became more critical in its tone and adopted a more aggressive posture clearly aligned with the opposition. Even when the government was at the height of its popularity, during Lula's second mandate, political commentators who were either clearly anti-Workers' Party (PT) or more scathing in their criticism tended to be in the majority in much of the media 
(Carvalho, 2016).

This change generally helped to create quite a negative feeling toward the PT, primarily among the middle classes, the main consumers of this political journalism. This feeling was to intensify after Dilma Rousseff was re-elected by a small margin, with voters being clearly divided by class and region. Roussef's votes came mainly from the lower income classes and from the north-east of the country (Vale, 2015). The figure below by Vale (2015) shows the distribution of votes per state in the second round of the 2014 presidential election (\% of vote).



Figure 1: Distribution of votes in the 2014 Brazilian presidential election (per state) (Vale, 2015).

At the same time, the consequences of the 2008 global crisis began to be felt across the country. Until Rousseff's first mandate, the country had managed to balance the public accounts. However, when the government boosted internal consumption by granting tax exemptions to certain industrial and infrastructure sectors by the end of her second term, public debt surged and became the target of strong criticism by financial commentators. At this point the PT lost most of support it might have had among the middle classes and in the industrialized south and south-east. Later, when the second major political scandal during the rule of the PT was to break - the discovery of a corruption scheme involving mainly allies of the PT but also marked by the participation and/or connivance of the PT itself - a political process was set in motion that included huge street demonstrations with extensive coverage and encouragement by the media. The government began to lose its support in Congress, a support which had never been very ideologically solid given the strength of the "lower clergy". The end result was that Dilma was impeached for a "crime of responsibility" on controversial grounds.

The political climate that ensued, however, did not help to restore peace. Accusations of corruption were levelled against a wide range of parties, including those that actively supported impeachment, such as the PT's long-standing adversary, the Brazilian Social Democracy Party (PSDB). Nowadays a centre-right party, the PSDB had held the presidency from 1995 to 2002 and had faced the PT in run-offs in all the presidential election since then. Historically a centreleft party, the PSDB had moved toward neoliberalism, although its membership later included more conservative candidates, with some in favour of more vigorous police action and tougher laws, as well as a morally conservative agenda. This slow ideological transformation was initially welcomed by part of the electorate, particularly middle and upper-class electors, but later proved to be insufficient to ensure their victory. 
Following Rousseff's impeachment, extensive reporting of the widespread involvement of political parties in the Petrobras scandal appears to have helped produce a profound aversion to politicians as a whole. The Petrobras scandal was revealed in 2014 by Operation Car Wash but the investigations lasted for another five years and were the subject of high media attention for the whole period. Investigators revealed that a "cartel of construction companies had bribed a small number of politically appointed directors of Petrobras in order to secure a virtual monopoly of oil-related contracts" (Boito \& Saad-Filho, 2016).

In parallel with this, Jair Bolsonaro became increasingly well known among a large swathe of the public. As previously mentioned, although he had been in politics for almost 30 years, Bolsonaro remained a minor figure until 2011, known only in his state, Rio de Janeiro, and popular only among the military (the armed forces as well as police and firefighters, who are members of the military in Brazil) and a small niche of electors in favour of repressive police action. In 2011, however, Bolsonaro took part in CQC (the acronym for "Whatever It Takes" in Portuguese), a TV programme that combines humour and political news, and answered questions sent in by members of the public. At the time, one of the presenters classified him as "polemical" and another said he had not the slightest idea who that congressman was. The objective appeared to be to ridicule him, and the programme featured humorous sound effects. The then congressman's answers ranged from homophobic to racist, and he praised the period of military dictatorship in Brazil. The interview sparked controversy, and Bolsonaro was invited to appear on the programme again the following week. He became a common attraction on CQC and other programmes that also explore the impact of the politically incorrect.

The congressman was gradually given more airtime on CQC and taken more seriously, while at the same time his legitimacy increased because of his popularity with the audience. A few months before Bolsonaro was elected, a former CQC reporter recalled with regret the visibility the programme had given the congressman. She said they were "clueless that a good chunk of the population would identify with him, with such a vile human being", admitting they "played a part" in the process. (2018, April 4)

In addition to CQC, other free-to-air TV programmes gave the then federal deputy airtime. In a recent study, Santos (2019) shows how, since 2010, Bolsonaro made an increasing number of appearances on the free-to-air TV programmes with the largest audiences. CQC helped particularly to bring Bolsonaro closer to a younger audience, together with the programme Pânico na Band, which also takes advantage of politically incorrect humor and created a special segment on the congressman, with 33 episodes each 9 minutes long in 2017.

In social media, Bolsonaro and his opinions became the subject of increasing debate and were vigorously rejected by the left but adopted as a symbol of the politically incorrect by sectors of the non-traditional right. The figure of a talkative, indiscreet congressman became a symbol for a subculture of youth groups-similar to those who frequent websites such as 4chan (Nagle, 2017) - for whom he became known as "the Myth", a mixture of iconoclasm, playful humour and conservatism. This connection with the politically incorrect was exploited by the administrators of the congressman's Facebook page since it was set up in June 2013 (Carlo and Kamradt, 2018). 


\section{WHATSAPP AND THE SPREAD OF MISINFORMATION / DISINFORMATION}

The political year of the last presidential election, 2018, was unusually troubled. Involved in various court cases, the then leader in the polls, former president Lula, was arrested in early April. The party was adamant that he should run for election even though there was little chance of his being allowed to do so by the legal authorities. Without Lula, Bolsonaro was ahead in the polls from the start - with a lead that varied but was always at least 20\% - although he was considered a passing phenomenon by most analysts and was expected to disappear as soon as the TV and radio campaigns started because he had very little airtime compared with the candidates for the traditional parties.

Another important event that helps describe the scenario in which WhatsApp had a significant role in politics is the strike/lockout organised by truck drivers in May 2018. Dissatisfied with the almost daily variations in fuel prices, which had begun to be adjusted in line with the US dollar and the price of oil, self-employed truck drivers and logistic companies started a protest that ended up bringing the country to a quite long and economically harmful standstill (Demori \& Locatelli, 2018). Using mainly WhatsApp, drivers organised roadblocks on the main highways, causing severe disruption to the supply of goods, including fuel and food (Rossi, 2018). Radical right-wing associations infiltrated these online groups, praising militarism as a solution for the country and sometimes clamouring for military intervention to depose the executive, legislature and judiciary.

Interested in understanding how fake news was spread by political groups on WhatsApp, Resende et al. (2019) collected data of two periods of intense activity in Brazil: the truck drivers' strike and the month prior to the first round of the elections. They sampled chat groups that did not necessarily have any association with a particular candidate, were open to the public (although the administrators could choose who was accepted or removed), having links to join in shared in websites or social networks, and could be found using the URL chat.whatsapp.com. The groups were chosen by the match of that URL with a dictionary containing the name of politicians, political parties, as well as words associated with political extremism. In all, they analysed 141 groups during the truck drivers' strike and 364 during the elections. The results show that $2 \%$ of the messages shared in these groups during the elections were audio messages, $9 \%$ were videos, $9 \%$ contained URLs to other sites and $15 \%$ were images. The other $65 \%$ were text messages with no additional multimedia content.

Resende et al. (2019) also developed an automated method for determining whether the shared images in the analysed groups had already been reviewed and rejected by fact-checking services. To that selection they added 15 more that were previously identified by the Brazilian factchecking agency, Lupa, as misinformation. Totalling 85 images that contained misinformation, they found that these were shared eight times more often than other 69,590 images, which were truthful or had not been denounced for checking by any independent agency.

Although the total number of images labeled as misinformation is relatively low - only $1 \%$ of the total number of images shared - these images were seen in $44 \%$ of the groups monitored during the election campaign period, which means they have a long reach. Upon investigation of such images, these researchers identified the groups in which the images appeared first, and remarked that a small number of groups seemed to account for dissemination of a large amount 
of images with misinformation. In our view, this fact indicates a more centralised and less distributed dissemination structure.

Another fact revealing a dynamic of relatively centralised dissemination is that the "behaviour" of image propagation including disinformation (which are images deliberately produced and/or tampered with) is significantly different from unchecked images. Comparing the structure of propagation of these two groups, particularly as to the time these images appeared on the Web and on WhatsApp and vice-versa, the authors noticed that $95 \%$ of the images with unchecked content were posted first on the Web and then in monitored WhatsApp groups. Only $3 \%$ of these images made the opposite route, and $2 \%$ appeared both on the Web and on WhatsApp on the first day. In contrast, only $45 \%$ of the images with misinformation appeared first on the Web, $35 \%$ were posted first on WhatsApp and $20 \%$ were shared in both platforms on the same day. According to the authors, this suggests "that WhatsApp acted as a source of images with misinformation during the election campaign period" (Resende et al., p.9.). Considering that an image with disinformation is deliberately produced and tampered with, the fact that WhatsApp is its first source of sharing in a much higher percentage than images with unchecked content (35\% in the first case versus $2 \%$ in the second case) is one more element indicating a relatively centralised and not fully spontaneous organisation of propagation of this type of content.

\section{DISINFORMATION IN WHATSAPP GROUPS}

As to the contents of images with disinformation, they reproduce many of the elements that were key in the rise of Bolsonaro and, later, during his election campaign. In this section we will analyse the top eight most shared images with disinformation in the month before the first round, using the same groups monitored by Resende et al. (2019) as our source. Our analysis is based on investigative work developed by the Agência Lupa and Revista Época, in partnership with the research project "Eleições sem Fake" (Resende et al. 2019; Marés, Becker and Resende, 2018). The news piece points out that none of the eight images analysed mentions the presidential candidates directly. All of them refer to topics that reinforce beliefs, perspectives and feelings that shaped the ideological base of Jair Bolsonaro's campaign. Anti-PT-ism, strongly boosted by the legacy media over the last few years, was one of the pillars of Bolsonaro's campaign, and it is the content of the most shared image with disinformation in the monitored groups in the month before the first round. As we can see, Figure 2 is a photo-montage that inserts a photo of the young ex-president of Brazil, Dilma Rousseff, beside the ex-president of Cuba, Fidel Castro. 


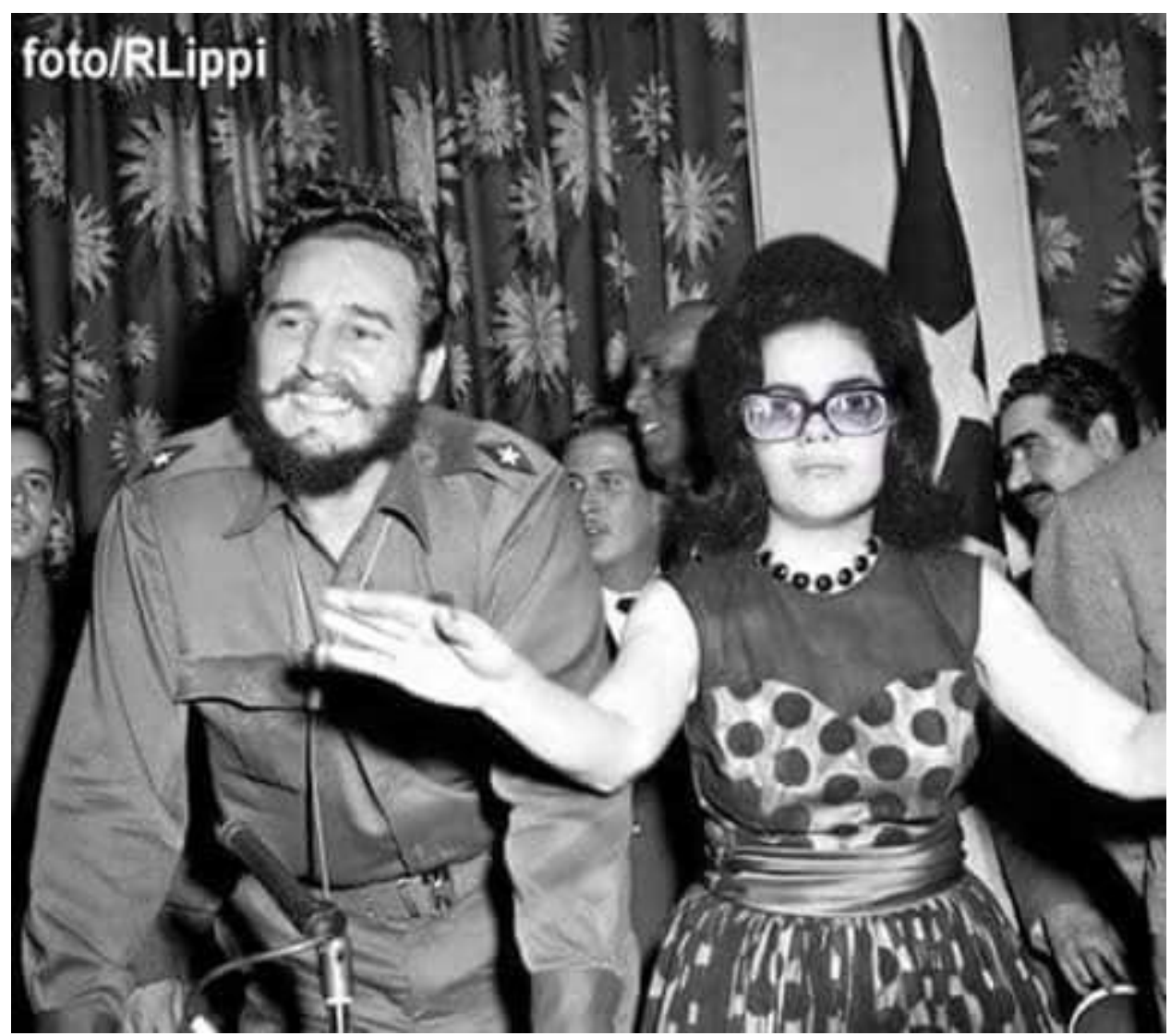

Figure 2: First most shared disinformation image on WhatsApp.

At the time the original photo of Fidel Castro was taken by John Duprey for the "NY Daily News" in 1959, president Dilma Rousseff was only 11 years old. Therefore, it is clearly a tampered image that intends to associate the PT with communism and Castroism. Such association was recurrent among Bolsonaro supporters during his campaign and antipetismo appears directly in three out of the eight most shared images with misinformation over the time period under analysis.

Another image with clear anti-PT-ist content (the fourth most shared image in the monitored groups) is an alleged criminal record of ex-president Dilma Rousseff during the times of the military dictatorship, in which she would be accused of being a terrorist/bank robber (Figure 3). This record was never issued by any official agency of the military government and has the same format as the third most shared image, this time showing José Serra, current senator of the republic for the PSDB party 3 . 


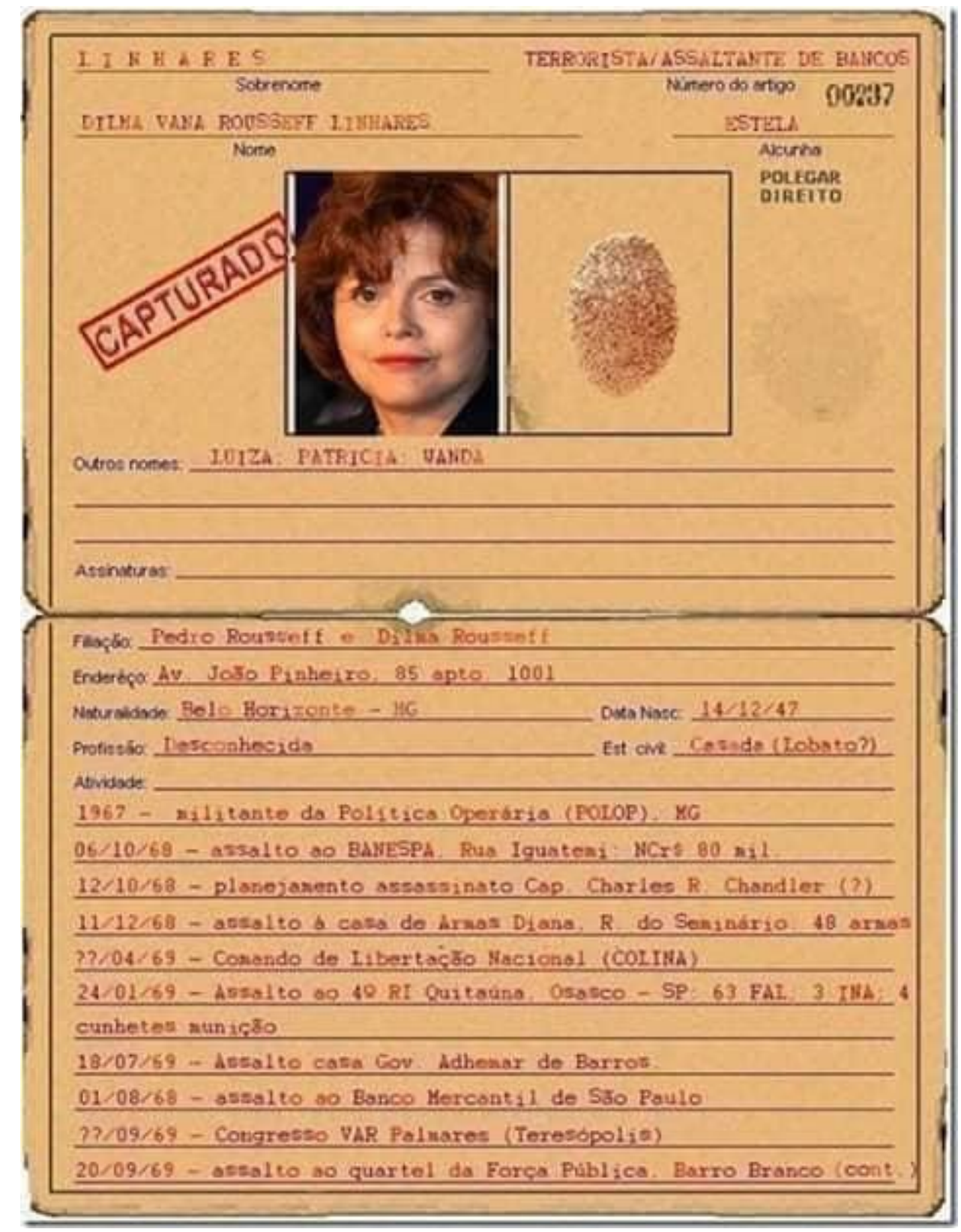

Figure 3: Fourth most shared disinformation image on WhatsApp.

Lastly, the third image with direct anti-PT-ism content (the eighth most shared image in the monitored WhatsApp groups) is the reproduction of a graph with false information comparing consumption of families over the last five years of PT government at that time with the expenditure of the government itself (Figure 4). Contrary to what the graph shows, the consumption of families did not decrease; instead it grew 1.8\% between 2011 and 2016, whereas expenditure of the public administration rose $3.1 \%$ during the period, and not $4 \%$ as the graph indicates. 


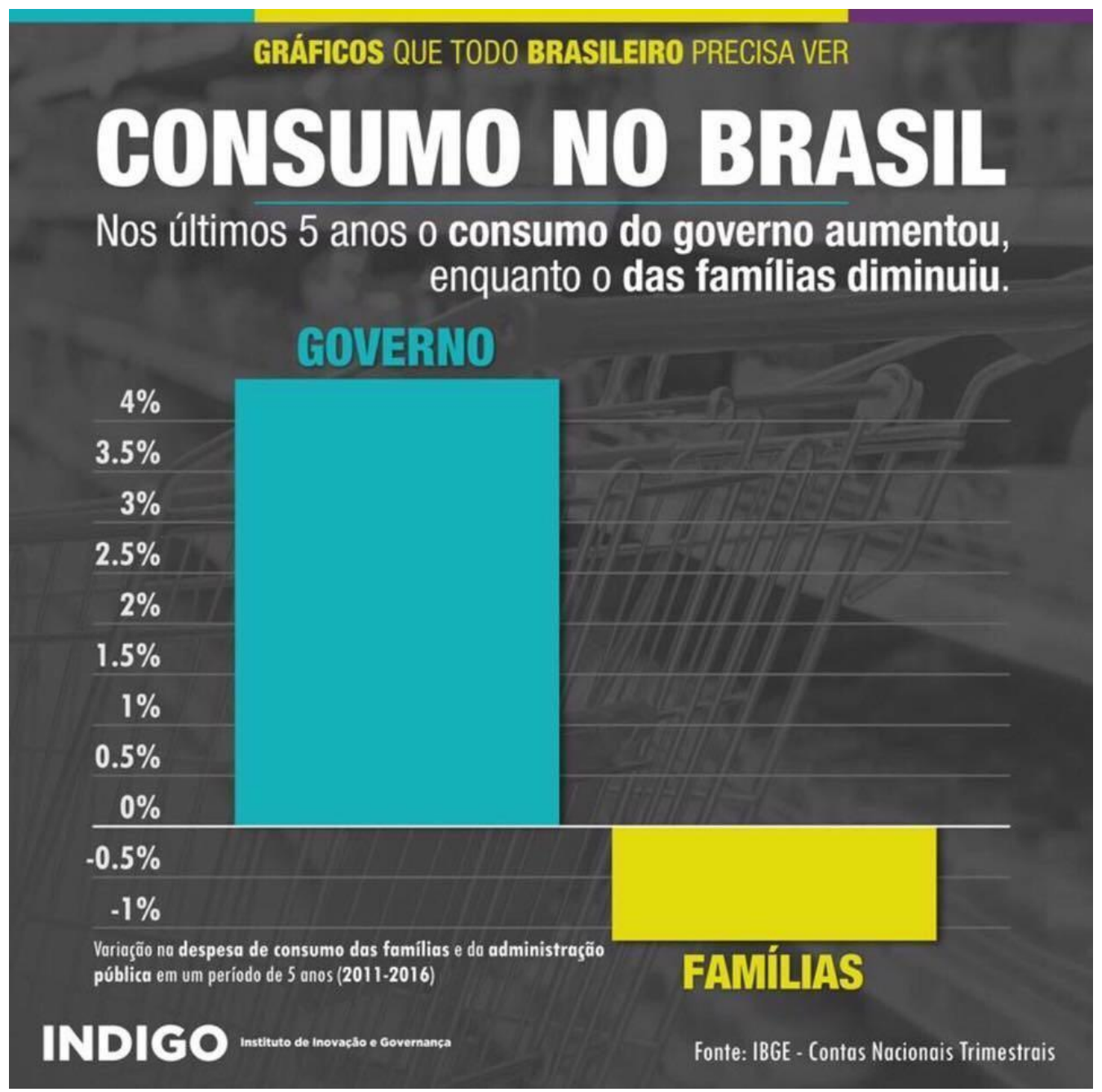

Figure 4: Eighth most shared disinformation image on WhatsApp.

The second most frequent topic in the most shared images with misinformation is attacks to the rights of LGBTs and women, appearing in three out of the eight most shared images. This kind of content, although not directly antipetismo, denies rights that were symbolically associated to leftist parties by Bolsonaro's campaign.

The fifth and sixth most shared images link these rights to sexualisation of childhood and lack of respect for religious beliefs, as shown in figures 5 and 6, respectively. Moreover, in the context of their sharing via WhatsApp, such images were associated with Rede Globo, the largest commercial open television network in the country. In figure 5, the legend of the image (which is in fact a photo of Heritage Pride March in New York in 2015) reads: "People from Globo-Trash who do not support Bolsonaro!!!". In figure 6, the image is shown with the sentence "Globo today". However, the image is a record of the Burning Man music festival that took place in the Desert of Nevada in 2011 in the US. It shows a man dressed as Jesus kissing Benjamin Rexroad, director of the "Corpus Christi" production. This image was published in O Globo newspaper at the time of the festival and not before the first round of the 2018 elections. The link of these images to the $O$ Globo newspaper is part of a campaign of disqualification of the TV station with the same name, Rede Globo. Bolsonaro supporters' strategy seems to be to legitimise the WhatsApp groups as more reliable sources of information than the legacy media. The Globo Network, historically linked to conservative economic and political interests in the country, was here associated with the propagation of hyper-sexualised and anti-Christian content. 
The other image (figure 7), which is part of this thematic group against LGBT and women's rights, is a montage of photos of different protests in churches. In one of the protests, a couple has sex inside a church in Oslo, Norway, in 2011. In the second one, a woman defecates on the stairway of a church in Buenos Aires, capital of Argentina, which happened when Maurício Macri won the 2015 presidential election. The caption of the false image reads "Feminists invade church, defecate and have sex”, and is in clear opposition to the \#EleNão movement. \#EleNão (\#NotHim) was a movement led by women that denounced Bolsonaro as misogynist, gathering thousands of people across Brazilian streets in the verge of the first round of the elections (Uchoa, 2018).

\section{ESSE É O DIREITO QUE ELES QUEREM}

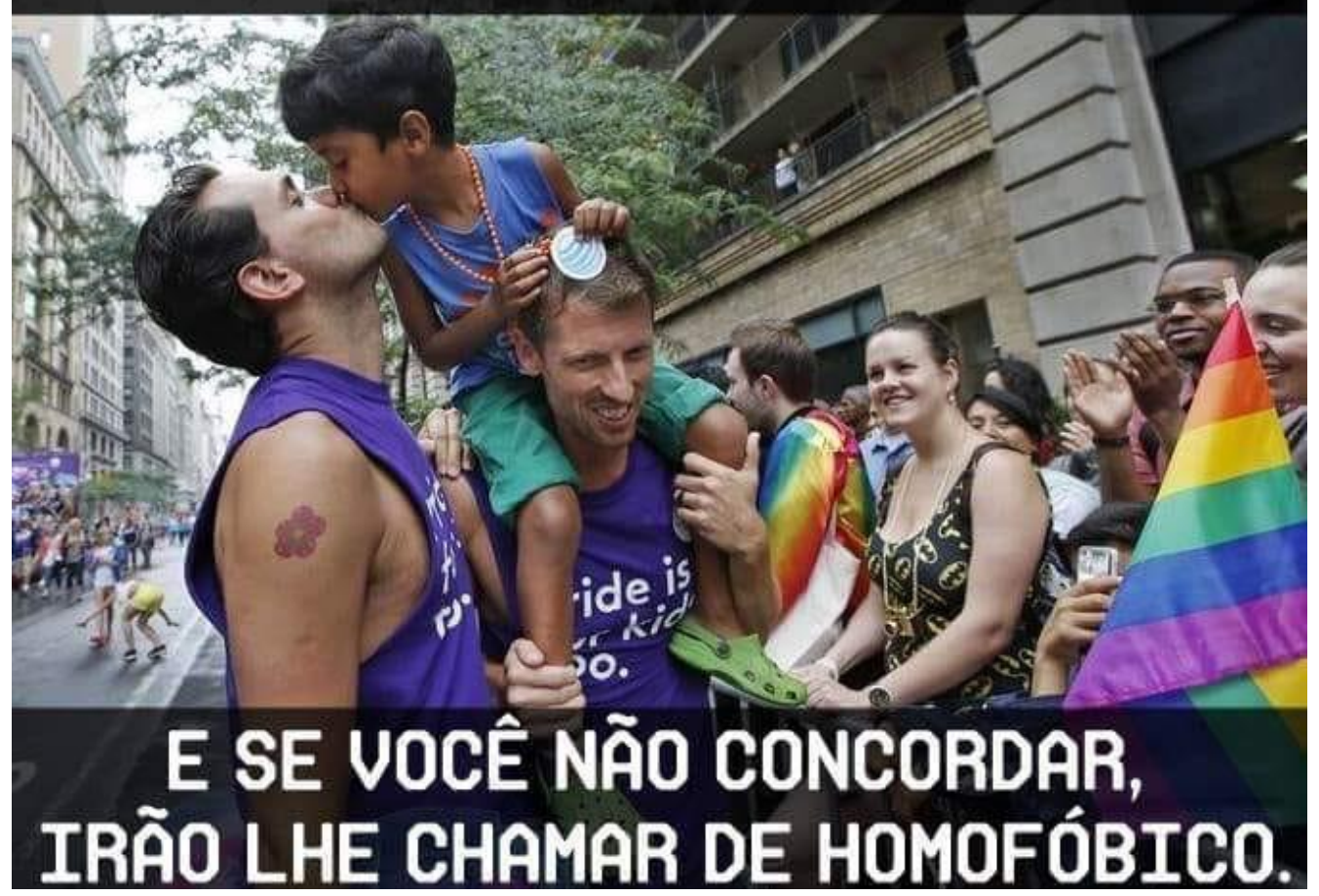

Figure 5: Fifth most shared disinformation image on WhatsApp. 


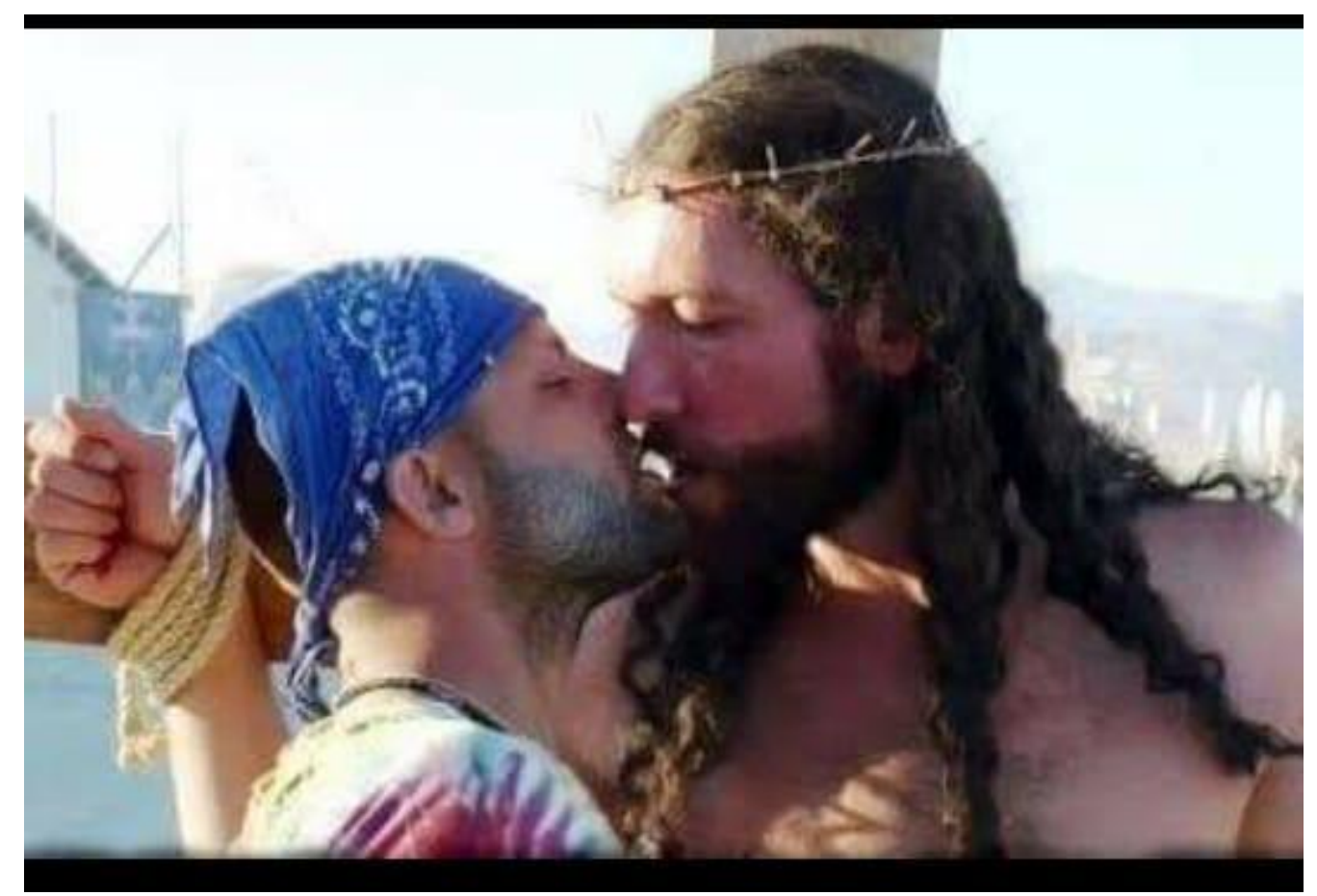

Figure 6: Sixth most shared disinformation image on WhatsApp.

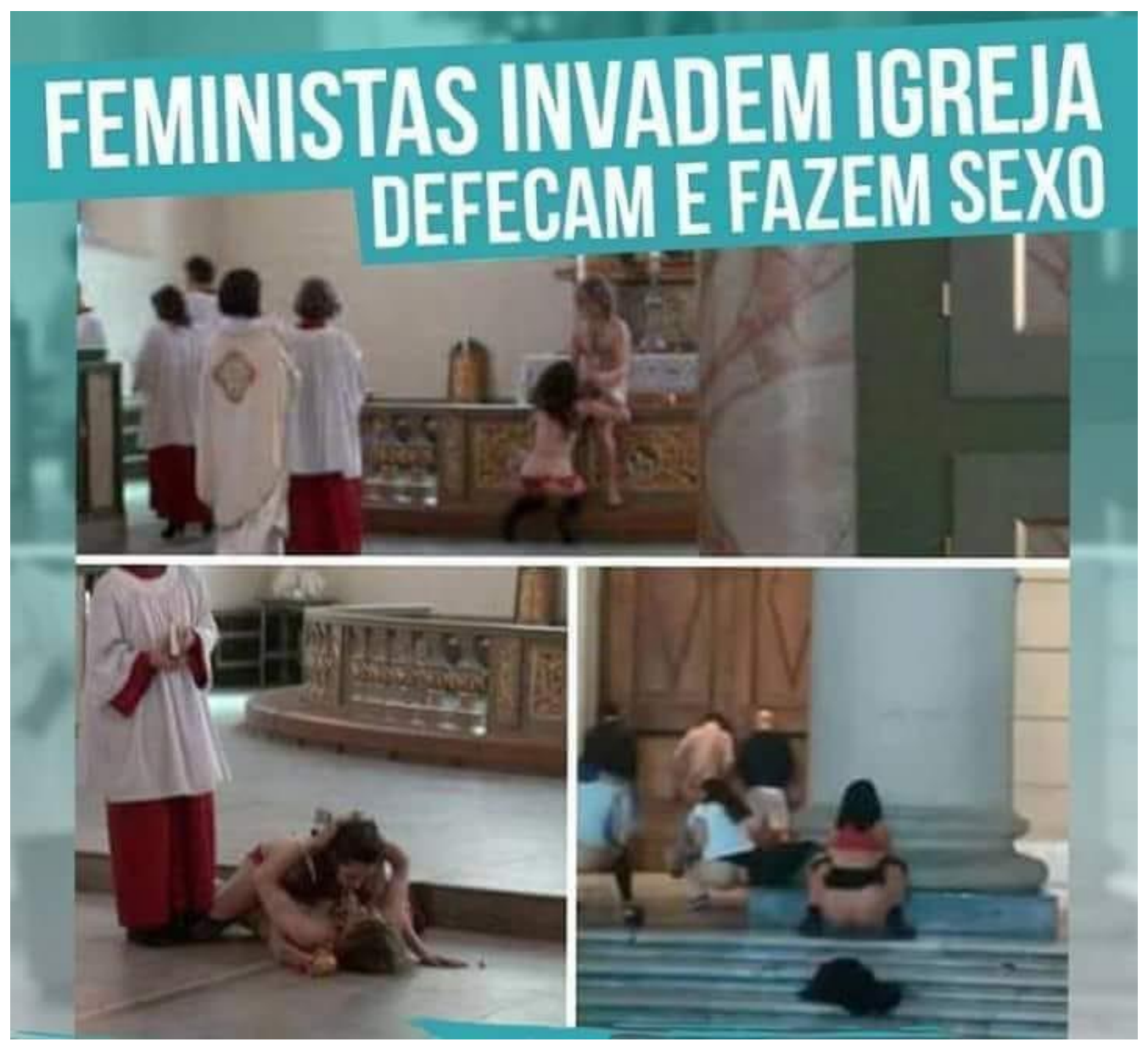

Figure 7: Seventh most shared disinformation image on WhatsApp. 


\section{USE OF ILLEGAL TACTICS}

In the second round of the elections, the newspaper Folha de S.Paulo managed to discover that businessmen had signed contracts of up to $\$ 3$ million US each with marketing agencies specialised in automated bulk messaging on WhatsApp (Melo, 2018). The most famous of the businessmen who were accused owns a retail sector company, which could suggest that the marketing methods used in his company could also be used in politics. The practice is illegal as donations from companies were forbidden in the last election. Furthermore, the businessmen were alleged to have acquired user lists sold by agencies as well as lists supplied by candidates. This practice is also illegal as only the candidate's user lists may be used. According to a report issued by Coding Rights (2018) involving interviews and document analyses of marketing agencies operating in Brazil, election campaigns in general combine a series of databases, associating public information, such as the Census, and data purchased from private companies such as Serasa Experian and Vivo (a telecom company owned by Telefónica). These databases include demographic data and telephone numbers (including the respective WhatsApp contacts).

According to Folha de S.Paulo's article, the marketing agencies are able to generate international numbers, which are used by employees to get around restrictions on spam and to administer or participate in groups. Off the record statements obtained by the newspaper from ex-employees and clients of the agencies, reveal that the administrators used algorithms that segmented group members into supporters, detractors and neutral members and defined the content sent accordingly. The most active Bolsonaro supporters were also allegedly contacted so that they could create even more groups in favour of the candidate (Melo, 2018). In a different article, the newspaper noted that some of these groups behaved like a military organisation and referred to themselves as a "virtual army" in favour of the candidate. According to the newspaper, the groups are divided into "brigades", "commands" and "battalions" and are formed mainly of youths, some under 18 years of age (Valente, 2018).

Investments on election campaigns were directed to several variations of digital advertising. Besides being less expensive, digital advertising can be an alternative to limited TV time, particularly for small political associations (Coding Rights, 2018). Digital campaigns included WhatsApp mainly because it is a platform with deep penetration in the population, considering, among other things, the practice of zero-rating policies. Zero-rated data refers to data that does not count toward the user's data cap (Galpaya, 2017). Telecom operators commonly offer free use of WhatsApp for pre-paid plans, which are the ones most commonly contracted by lower classes. Even if the user doesn't have any credits left for accessing the internet, they keep sending and receiving text and media content on their WhatsApp chat groups and from individual users. An accurate image is described by Luca Belli: "fact-checking is too expensive for the average Brazilian” (2018).

Rules approved for the Brazilian 2018 elections permitted candidates to buy advertisements on social media and to spread content using message platforms. However, WhatsApp does not offer micro-segmentation as a service, which would allow advertisements to be directed to a certain audience, like Facebook does. Marketing agencies ended up playing that role, not always using legally collected information on voters.

Audi \& Dias (2018) reported that agencies in the business of political advertising use software that monitors different interest groups - not only those of political discussion - to prospect 
voters and supporters. The users are measured in terms of their mood and receptivity towards campaign messages. By doing so, these agencies manage to identify the ideal target population and the right time to send each type of content. According to the article, "messages that reach a diabetic 60-year old man from São Paulo State are different from those sent to a north-eastern woman who lives on minimum wage". Audi \& Dias (2018) had access to one of the software programmes used during the last elections in Brazil, WNL, a version used for the campaign of a non-identified politician. The software programme monitored and distributed contents in over 100 WhatsApp groups that ranged from diabetics discussion groups, soccer team supporters, Uber drivers, advertising of job vacancies and even workmates and neighbours.

Such segmentation was refined by the monitoring of reactions to contents posted, rated as positive, negative or neutral reactions. Users rated as positive keep receiving similar information in favour of the candidate. Those rated as neutral get mostly materials contrary to the opponent. Negative users start getting a more incisive treatment, receiving content that would tend to "target values dear to the person, such as family and religion, in an attempt to inflate rejection towards the candidate's competitor". By monitoring these reactions, users are segmented in individual files and then classified into groups according to specific topics - such as church, "gay kit", family, communism, weapons, privatisation, etc. Moreover, this software programme enables those that monitor the groups to collect and select keywords in order to discover specific interests: "For example, a patient with cancer speaks about his/her condition and treatment. The system collects these data and finds other people in similar conditions. They start to get content with the policies of the candidate for health, for example" (Audi and Dias, 2018).

It should be noted that this micro-segmentation and micro-targeting are integral to the way advertisements on platforms work. Facebook, for instance, announced some special transparency policies for political ads during the election period (Valente, 2018). However, due to the nature and architecture of WhatsApp, the visibility of content spreading strategies on a platform such as it is minimal, and this prevents users to realise that they are being the target of persuasion strategies. We will return to this issue in the conclusion, but it must be pointed out that using this platform for election campaigns is structurally questionable. If we consider only the methods used by AM4 Company, which openly worked in Jair Bolsonaro's campaign spreading contents to 1,500 WhatsApp groups, there are already reasons for concern, since such content is not explicitly distributed as part of an election advertising campaign. It is rather distributed as content shared by common users in groups with a supposedly symmetrical interaction structure. According to a statement of the company's founding partner: "what we do is curator-ship of contents created by supporters" (Soares, 2018). The company owner also stated that a series of content that fed 1,500 WhatsApp groups on a daily basis were part of the strategy of the company hired by PSL, which operated since the pre-campaign, to revert negative episodes in favour of Bolsonaro's campaign.

\section{WHATSAPP GROUP DYNAMICS}

Before developing a formal research interest in the use of WhatsApp during the elections we started a participatory observation process at political chat groups on WhatsApp. Initially, we were interested in understanding how the app was being used by truck drivers for organising its protests. Later, we noticed that many groups we found were also occupied by radicals in favour of a return to the military dictatorship and supporters of Jair Bolsonaro. This helped us to understand the dynamics of those groups and how some more prominent members acted to manage the discussions or the posting of content. 
Various groups were short-lived and rapidly replaced by other groups that were advertised in the "dying" groups. Until the election day, and some weeks before, we tried to follow the discussion of at least three groups on WhatsApp and two on Telegram. Some of the groups were occasionally invaded by users who posted pornographic content or advertised illegal services, such as pirate IP TV and false diplomas, cloned credit cards and counterfeit money. As observed in field work, in the case of one particular group on Telegram, the group became a pirate IP TV sales channel as soon as the elections were over.

At the end of the elections, it was observed that new groups were set up with a new mission: to act as direct communication channels between supporters of the new president. One of these went by the name of Bolsonews TV. There is little discussion in these groups and only a few members are responsible for almost all the content sent to the groups or forwarded from other groups. A frequently repeated claim is that one should not believe in the legacy media because it is controlled by communists and left-wing individuals; according to the people who send these messages, only some YouTubers, journalists, bloggers and politicians can be trusted. Before the elections, material from the legacy media that was highly critical of the PT was frequently shared, particularly if it was produced by commentators who were considered right wing. After the elections, when the criticism was aimed more at the new government, and even when it came from commentators who were considered right wing, this type of content became less common. Any critical comments in groups clearly identified with Bolsonaro led to the author being removed from the group and accusations that he/she was a supporter of the PT who had infiltrated the group. The telephone numbers of people accused of supporting the PT circulate regularly, and group moderators are warned to exclude these people from groups.

Analysing the flow of messages between political groups during the elections, Resende et al. (2018) identified characteristics that indicated the presence of clusters of groups with members in common. They constructed a graphical model of the relationship between members, which revealed a network of users who were associated because they shared images in at least one common group. "We note a large number of users blending together connecting to each other inside those groups. Most users indeed form a single cluster, connecting mostly to other members of the same community. On the other hand, there are also a few users who serve as bridges between two or more groups linked by multiple users at the same time. Furthermore, a few users work as big central hubs, connecting multiple groups simultaneously. Lastly, some groups have a lot of users in common, causing these groups to be strongly inter-connected, making it even difficult to distinguish them" (2019, p. 6). This would suggest that WhatsApp is working not so much as an instant messaging app but as a social network, like Twitter and Facebook. Other evidence, as shown above, allows us to conclude that these groups may be centrally managed, although this is invisible to the ordinary user.

\section{CONCLUSION}

Commenting on the use of micro-targeting in campaigns, Kreiss points out that it is "likely most effective in the short run when campaigns use them to mobilize identified supporters or partisans" (2017). It seems to be the case of what happened in Brazil in the 2018 elections, in which a candidate was able to tap into a conservative sentiment, harnessing it against the progressive field.

Even though it is not possible to fully confirm the hypothesis that WhatsApp has been used as an effective tool to direct messages to micro-segmented voters, we have shown that the 
campaign of Jair Bolsonaro used the app to deliver messages (and disinformation) to exacerbate political feelings present in the political debate of the legacy media - antipetismo (Davis \& Straubhaar, 2019) - and add to them much more conservative elements in the moral field (antifeminism and anti-LGBT), which brought back topics from the times of the military dictatorship (anti-communism). Beyond the effects on the left, the radicalisation promoted by Bolsonaro's campaign was able to neutralise any other candidate on the centre, even on the centre-right, associating them with the establishment and with the notion of a corrupt political system. In the symbolic assemblage (Norton, 2017) that was formed, the elected candidate ended up representing the most effective answer against the political system, although many voted for him for different reasons. In a similar fashion to Trump, Bolsonaro "ran an insurgent campaign that called for shaking up the system" (Kivisto, 2019, p. 212)

There is enough evidence that the WhatsApp chat groups feature was weaponised by Bolsonaro supporters. Although WhatsApp does not provide a service for micro-targeting audiences, there is evidence that third party companies, dedicated to non-political marketing campaigns, provided that kind of service in the context of elections, sometimes using illegal databases. There are reports that Haddad's campaign has also used WhatsApp to deliver messages to voters (Rebello, Costa, \& Prazeres, 2018). However, as the sample collected by Resende et al. (2019) suggests, there is no evidence that the left coalition has employed the same tactics as Bolsonaro's in secretly managing multiple WhatsApp chat groups.

Among the many problems involved in the use of a platform like WhatsApp in an election campaign, we would like to point out one in particular: the invisibility of the actors that produce, monitor, distribute and/or direct the contents viewed and/or shared by most users. The current architecture of the platform does not allow, once appropriated for purposes of election campaigns and micro-targeting, users to notice or become aware that they are being monitored and managed. Writing on voter surveillance in Western societies, Bennett reminds us that "surveillance has particular, and somewhat different, effects depending on whether we are consumers, employees, immigrants, suspects, students, patients or any number of other actors" (2015, p. 370). The case of use of WhatsApp in Brazilian elections shows how a surveillant structure was built on top of a group message service that allegedly uses cryptography to protect its user's privacy.

Resende et al. (2019) characterised a network structure of the monitored WhatsApp groups that evidence a coordinated activity of some members. There are no clear means for regular WhatsApp chat group members to notice if they are being monitored or laterally surveilled by other group members or even other second-hand observers outside the groups. Studies on perception and experience of Facebook users show that when they notice that a post is sponsored they tend to be less persuaded than when exposed by a regular post by a friend or acquaintance (Kruikemeier et al., 2016). But unlike Facebook, where users can have a huge number of connections although a great part of them may not be very close or not close at all, most contacts of WhatsApp users are closer to a personal circle, thus setting a relationship of trust with the content received. Writing on family WhatsApp chat groups in Brazil, Benjamin Junge classifies them as both "public" of sorts, an "open space for the sharing of information and opinions" (2019, pp. 13-14), and closed in the strict sense, because they are only accessible to family members. Although this trust-based relation may be transformed when the user is a member of larger groups, the experience of proximity and connection with the members of a group is bigger than, for instance, among Facebook friends and Twitter followers. WhatsApp favours a stronger relationship of trust between group members and the content shared, which implies that is a more susceptible field for the spread of misinformation. Cesarino (2019a) posits 
"trust" as one of the affordances of the WhatsApp platform, affirming that most of the political content forwarded to its users during the 2018 election was pushed by friends or family members.

Possible asymmetries of information, persuasion tactics and/or influence strategies within chat groups are rather hard to detect. In countries like Brazil, this condition is reinforced by the impossibility that many users have to reach beyond the platform to check information shared, something that might provide a context or additional information about the contents circulating in the platform. With the zero-rating plans offered by telecom companies, users are subject to tariffs that they cannot afford if they seek other sources of information. This perceptive confinement is particularly worrying in a context of the wide dissemination of disinformation, just like what happened in the 2018 election period, since most users are not only unaware of the authorship of the contents that reach them, but also they cannot reasonably check and verify such contents. The 'near-sighted" environment (in fact the most appropriate eye disorder here would be loss of peripheral sight) of WhatsApp is also favoured by its one-to-one communication structure, which prevents side visibility, transversal or common visibility in the platform. The lack of a common field of visibility would not be a problem if WhatsApp restricted its stated or projected technical functionality - that of being an instant messenger. However, when the tool begins to function as a typical social network - as stated by Resende et al. (2019), and starts to be massively appropriated for political campaigns, it is critical to have more symmetric relationships of visibility, as well as the possibility to build a common visible field that can be debated, examined and audited.

At least since the 2014 elections and especially after the contested impeachment of President Dilma Rousseff (PT), Brazil lives in a period of political and institutional instability. Recently leaked messages exchanged by prosecutors and judges involved in the investigation of corruption scandals help to draw a picture of a justice system contaminated by political goals (Fishman et al., 2019). That struggle certainly played a role in the ineffectiveness of the electoral legislation to curb the illegal use of WhatsApp in the 2018 elections. We described in this article many of the illegalities that surrounded the electoral process. In 2019, the Brazilian Congress approved a data protection law in many aspects compliant with the EU's General Data Protection Regulation (GDPR) that can help to strengthen the fairness of future elections (if and when the country can restore its political and institutional normalcy).

However, as we hope to have exposed here, there is a complex dynamic between the legacy media and what is created and shared by political actors and supporters. Much of the disinformative content we have analysed was produced having as background a radicalisation trend noticed on the legacy media. The fact that the means of communication in Brazil are highly concentrated in the hands of a few groups and lacks political diversity certainly played an important role in paving a way for political radicalisation. Zero-rating policies that fuels the popularity of one specific platform (WhatsApp) and curbs users from accessing a full functioning internet obviously are a practical impediment for a voter that could be educated to adequately research and check the news stories they receive. 


\section{REFERENCES}

"A gente, infelizmente, contribuiu”, diz Monica Iozzi sobre popularidade de Bolsonaro - Emais ["Unfortunately, we contributed," says Monica Iozzi about Bolsonaro's popularity]. (2018, April 4). O Estado de S.Paulo. Retrieved April 1, 2019 from https://emais.estadao.com.br/noticias/gente,agente-infelizmente-contribuiu-diz-monicaiozzi-sobre-popularidade-de-bolsonaro,70002254686

Armijo, L. E., \& Rhodes, S. D. (2017). Explaining infrastructure underperformance in Brazil: Cash, political institutions, corruption, and policy Gestalts. Policy Studies, 38(3), 231-247. https://doi.org/10.1080/01442872.2017.1290227

Audi, A., \& Dias, T. (2018, October 22). VÍDEO: Seu número de telefone vale 9 centavos no zap dos políticos [VIDEO: Your phone number is worth 9 cents at the politicians' zap]. The Intercept. Retrieved July 15, 2019, from https://theintercept.com/2018/10/22/whatsapppoliticos/

Avelar, D. (2019, October 30). WhatsApp fake news during Brazil election 'favoured Bolsonaro'. The Guardian. Retrieved from https://www.theguardian.com/world/2019/oct/30/whatsappfake-news-brazil-election-favoured-jair-bolsonaro-analysis-suggests

Baldwin-Philippi, J. (2017). The Myths of Data-Driven Campaigning. Political Communication, 34(4), 627-633. https://doi.org/10.1080/10584609.2017.1372999

Belli, L. (2018, December 5). WhatsApp skewed Brazilian election, proving social media's danger to democracy. The Conversation. Retrieved 4 December 2019, from http://theconversation.com/whatsapp-skewed-brazilian-election-proving-social-medias-danger -to-democracy-106476

Bennett, C. J. (2015). Trends in Voter Surveillance in Western Societies: Privacy Intrusions and Democratic Implications. Surveillance \& Society, 13(3/4), 370-384.

https://doi.org/10.24908/ss.v13i3/4.5373

Bodó, B., Helberger, N., \& de Vreese, C. H. (2017). Political micro-targeting: A Manchurian candidate or just a dark horse? Internet Policy Review, 6(4).

https://doi.org/10.14763/2017.4.776

Boito, A., \& Saad-Filho, A. (2016). State, State Institutions, and Political Power in Brazil. Latin American Perspectives, 43(2), 190-206. https://doi.org/10.1177/0094582X15616120

Bradshaw, S., \& Howard, P. N. (2018). Challenging Truth and Trust: A Global Inventory of Organized Social Media Manipulation [Report]. Oxford: Project on Computational Propaganda, Oxford Internet Institute. Retrieved from https://comprop.oii.ox.ac.uk/research/cybertroops2018/

Carlo, J. D., \& Kamradt, J. (2018). Bolsonaro e a cultura do politicamente incorreto na política brasileira [Bolsonaro and the culture of the politically incorrect in Brazilian politics]. Teoria e Cultura, 13(2). https://doi.org/10.34019/2318-101X.2018.v13.12431

Carvalho, R. (2016). O governo Lula e a mídia impressa: Estudo sobre a construção de um pensamento hegemônico [The Lula government and the printed media: Study on the 
construction of hegemonic thinking]. São Paulo: Pontifícia Universidade Católica de São Paulo. Retrieved from https://tede2.pucsp.br/handle/handle/3708

Cesarino, L. (2019). On Digital Populism in Brazil. PoLAR: Political and Legal Anthropology Review. Retrieved from https://polarjournal.org/2019/04/15/on-jair-bolsonaros-digitalpopulism/

Cesarino, L. (2019a). Digitalização da política: reaproximando a cibernética das máquinas e a cibernética da vida [Digitization of policy: bringing cybernetics closer to machines and cybernetics to life]. Manuscript submitted for publication.

Coding Rights. (2018). Data as a tool for political influence in the Brazilian elections. Retrieved from Coding Rights website: https://www.codingrights.org/data-as-a-tool-for-politicalinfluence-in-the-brazilian-elections/

Davis, S., \& Straubhaar, J. (2019). Producing Antipetismo: Media activism and the rise of the radical, nationalist right in contemporary Brazil. International Communication Gazette, 82(1), 82-100. https://doi.org/10.1177/1748048519880731

Demori, L., \& Locatelli, P. (2018, June 5). Massive Truckers' Strike Exposes Political Chaos as Brazil Gears Up for Elections in October. The Intercept. Retrieved 28 November 2019, from https://theintercept.com/2018/o6/05/brazil-truckers-strike/

Fishman, A., Martins, R. M., Demori, L., Greenwald, G., \& Audi, A. (2019, June 17). “Their Little Show": Exclusive: Brazilian Judge in Car Wash Corruption Case Mocked Lula's Defense and Secretly Directed Prosecutors' Media Strategy During Trial. The Intercept. Retrieved July 12, 2019, from https://theintercept.com/2019/o6/17/brazil-sergio-moro-lula-operation-car-wash/

Foley, C. (2019). Balls in the air: The macho politics of Brazil's new president plus ex-president Dilma Rousseff's thoughts on constitutional problems. Index on Censorship, 48(2), 26-28. https://doi.org/10.1177/0306422019858496

Galpaya, H. (2017, February) Zero-rating in Emerging Economies. [Paper No. 47]. Waterloo, Ontario; London: Global Commission on Internet Governance; Centre for International Governance Innovation; Chatham House. Retrieved December 14, 2019 from https://www.cigionline.org/sites/default/files/documents/GCIG\%20no.47_1.pdf

Haggerty, K., \& Ericson, R. (Eds.). (2006). The New Politics of Surveillance and Visibility. Toronto; Buffalo; London: University of Toronto Press. Retrieved from http://www.jstor.org/stable/10.3138/9781442681880

Hunter, W., \& Power, T. J. (2005). Lula's Brazil at Midterm. Journal of Democracy, 16(3), 127-139. https://doi.org/10.1353/jod.2005.0046

Issenberg, S. (2012). The Victory Lab: The Secret Science of Winning Campaigns. New York: Crown Publishers.

Joyce, S. N. (2013). A Kiss Is (Not) Just a Kiss: Heterodeterminism, Homosexuality and TV Globo Telenovelas. International Journal of Communication, 7. Retrieved from https://ijoc.org/index.php/ijoc/article/view/1832

Junge, B. (2019). “Our Brazil Has Become a Mess”: Nostalgic Narratives of Disorder and 
Disinterest as a "Once-Rising Poor" Family from Recife, Brazil, Anticipates the 2018 Elections. The Journal of Latin American and Caribbean Anthropology.

https://doi.org/10.1111/jlca.12443

Kivisto, P. (2019). Populism's Efforts to De-legitimize the Vital Center and the Implications for Liberal Democracy. In J. L. Mast \& J. C. Alexander (Eds.), Politics of Meaning/Meaning of Politics: Cultural Sociology of the 2016 U.S. Presidential Election (pp. 209-222). https://doi.org/10.1007/978-3-319-95945-0_12

Kreiss, D. (2017). Micro-targeting, the quantified persuasion. Internet Policy Review, 6(4). https://doi.org/10.14763/2017.4.774

Kruikemeier, S., Sezgin, M., \& Boerman, S. C. (2016). Political Microtargeting: Relationship Between Personalized Advertising on Facebook and Voters' Responses. Cyberpsychology, Behavior, and Social Networking, 19(6), 367-372. https://doi.org/10.1089/cyber.2015.0652

Lafuente, J. (2018, October 9). Bolsonaro's surprise success in Brazil gives new impetus to the rise of the far right. El País. Retrieved from

https://elpais.com/elpais/2018/10/o9/inenglish/1539079014_311747.html

Machado, C. (2018, November 13). WhatsApp's Influence in the Brazilian Election and How It Helped Jair Bolsonaro Win [Blog Post]. Council on Foreign Relations. Retrieved from https://www.cfr.org/blog/whatsapps-influence-brazilian-election-and-how-ithelped-jair-bolsonaro-win

Magenta, M., Gragnani, J., \& Souza, F. (2018, October 24). WhatsApp 'weaponised' in Brazil election. BBC News. Retrieved from https://www.bbc.com/news/technology-45956557

Marés, C., Becker, C., \& Resende, L. (2018, October 18). Imagens falsas mais compartilhadas no WhatsApp não citam presidenciáveis, mas buscam ratificar ideologias [WhatsApp's most shared fake images don't quote presidential, but seek to ratify ideologies]. Retrieved July 15, 2019, from Agência Lupa website: https://piaui.folha.uol.com.br/lupa/2018/10/18/imagens-falsaswhatsapp-presidenciaveis-lupa-ufmg-usp/

Moura, M., \& Michelson, M. R. (2017). WhatsApp in Brazil: Mobilising voters through door-todoor and personal messages. Internet Policy Review, 6(4). Retrieved from https://doi.org/10.14763/2017.4.775

Melo, P. C. (2018, October 18). Empresários bancam campanha contra o PT pelo WhatsApp [Business owners campaign against PT through WhatsApp]. Folha de S.Paulo. Retrieved from https://www1.folha.uol.com.br/poder/2018/10/empresarios-bancam-campanha-contra-opt-pelo-whatsapp.shtml

Melo, P. C. (2019, October 9). WhatsApp Admits to Illegal Mass Messaging in Brazil's 2018. Folha de S.Paulo. Retrieved from https://www1.folha.uol.com.br/internacional/en/brazil/2019/10/whatsapp-admits-to-illegal-m ass-messaging-in-brazils-2018.shtml

Nascimento, W. (2019). Fragmentação partidária e partidos pequenos no Brasil (1998-2014) [Party fragmentation and small parties in Brazil (1998-2014)]. Conversas \& Controvérsias, 5(2), 285-305. https://doi.org/10.15448/2178-5694.2018.2.31837 
Nagle, A. (2017). Kill All Normies: Online Culture Wars From 4Chan And Tumblr To Trump And The Alt-Right. John Hunt Publishing.

Norton, M. (2017). When voters are voting, what are they doing?: Symbolic selection and the 2016 U.S. presidential election. American Journal of Cultural Sociology, 5(3), 426-442. https://doi.org/10.1057/s41290-017-0040-z

Ramalho, R. (2018). TSE apresenta previsão do tempo de propaganda no rádio e na TV para cada candidato à Presidência [TSE presents radio and TV advertising weather forecast for each presidential candidate]. Retrieved 27 November 2019, from G1 website:

https://g1.globo.com/politica/eleicoes/2018/noticia/2018/o8/23/tse-

apresenta-previsao-do-tempo-de-propaganda-no-radio-e-na-tv-

para-cada-candidato-a-presidencia.ghtml

Rebello, A., Costa, F., \& Prazeres, L. (2018, October 26). PT usou sistema de WhatsApp; campanha de Bolsonaro apagou registro de envio [PT used WhatsApp system; Bolsonaro campaign deleted submission record]. Retrieved 5 December 2019, from UOL Eleições 2018 website: https://noticias.uol.com.br/politica/eleicoes/2018/noticias/2018/10/26/bolsonaroapagou-registro-whatsapp-pt-haddad-usou-sistema-mensagens.htm

Resende, G., Melo, P., Sousa, H., Messias, J., Vasconcelos, M., Almeida, J., \& Benevenuto, F. (2019). (Mis)Information Dissemination in WhatsApp: Gathering, Analyzing and Countermeasures. WWW' 19: The World Wide Web Conference, 818-828.

https://doi.org/10.1145/3308558.3313688

Rossi, A. (2018, June 2). Como o WhatsApp mobilizou caminhoneiros, driblou governo e pode impactar eleições [How WhatsApp mobilized truckers, dribbles government and can impact elections]. BBC News Brazil. Retrieved March 18, 2019, from https://www.bbc.com/portuguese/brasil-44325458

Soares, J. (2018, October 7). Time digital de Bolsonaro distribui conteúdo para 1.500 grupos de WhatsApp [Digital Scholarship Team distributes content to 1,500 WhatsApp groups]. O Globo. Retrieved from https://oglobo.globo.com/brasil/time-digital-de-bolsonaro-distribui-conteudopara-1500-grupos-de-whatsapp-23134588

Tardáguila, C., Benevenuto, F., \& Ortellado, P. (2018, October 19). Opinion | Fake News Is Poisoning Brazilian Politics. WhatsApp Can Stop It. The New York Times. Retrieved from https://www.nytimes.com/2018/10/17/opinion/brazil-election-fake-news-whatsapp.html

Uchoa, P. (2018, September 21). Why Brazilian women are saying \#NotHim. BBC News. Retrieved from https://www.bbc.com/news/world-latin-america-45579635

Vale, H. F. D. (2015). Territorial Polarization in Brazil's 2014 Presidential Elections. Regional \& Federal Studies, 25(3), 297-311. https://doi.org/10.1080/13597566.2015.1060964

Valente, J. (2018, July 24). Facebook vai dar transparência para anúncios eleitorais no Brasil [Facebook to provide transparency for election announcements in Brazil]. Retrieved December 4, 2019, from Agência Brasil website:

http://agenciabrasil.ebc.com.br/politica/noticia/2018-07/facebook-vai-dar-transparencia-para -anuncios-eleitorais-no-brasil

Valente, R. (2018, October 26). Grupos de WhatsApp simulam organização militar e 
compartilham apoio a Bolsonaro [WhatsApp Groups simulate military organization and share support for Bolsonaro]. Folha de S.Paulo. Retrieved from https://www1.folha.uol.com.br/poder/2018/10/gruposde-whatsapp-simulam-organizacao-militar-e-compartilham-apoio-a-bolsonaro.shtml

Woolley, S. C., \& Howard, P. N. (2017). Computational Propaganda Worldwide: Executive Summary [Working Paper No. 2017.11]. Oxford: Project on Computational Propaganda, Oxford Internet Institute. Retrieved from https://comprop.oii.ox.ac.uk/research/workingpapers/computational-propaganda-worldwide-executive-summary/

\section{FOOTNOTES}

1. We describe antipetismo as "an intensely personal resentment of the Workers' Party (PT)".

2. Donations from companies, were however not allowed in the last election, only from individuals.

3. According to Lupa Agency, both fake criminal records circulated for the first time in the presidential election in 2010, when Dilma Rousseff (PT) was the first woman to be elected president of Brazil, beating José Serra (PSDB). It must be pointed out that, before that, the printed newspaper with the greatest circulation in Brazil - A Folha de S.Paulo - published in 2009 a version of the false criminal record of Dilma Rousseff, who at the time was Chief of Staff of the government of then-president Luiz Inácio Lula da Silva (PT). The newspaper corrected the mistake 20 days after publishing the false information. Cf.

https://www1.folha.Figureuol.com.br/folha/brasil/ultg6u556855.shtml 